Vol. 8 (9), pp. 203-208, 2018

ISSN: 2276-7770; ICV: 6.15

Copyright @2018, the copyright of this article is retained by the author(s)

DOI Link: http://doi.org/10.15580/GJAS.2018.9.052316096

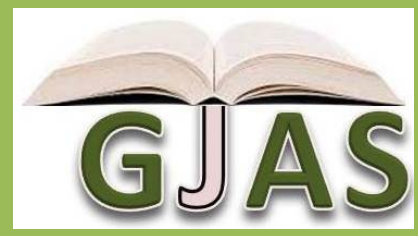

http://gjournals.org/GJAS

\title{
Influence of Agricultural Extension Delivery on Adoption of Fruit Crop Technologies: A Case Study of Ogbomoso Mango Production
}

\section{ALAMU 0. ${ }^{1}$, OSEWA S.O. ${ }^{1}$ and SANGOTEGBE N.S. ${ }^{2}$}

\author{
${ }^{1}$ Extension and Linkages Department, National Centre for Genetic Resources and Biotechnology \\ PMB 5382 Moor Plantation Ibadan, Nigeria. \\ ${ }^{2}$ Department of Agricultural Extension and Rural Development, University of Ibadan, Ibadan \\ Nigeria.
}

ARTICLE INFO

Article No.: 052316096

Type: Research

DOI: 10.15580/GJAS.2018.9.052316096

Submitted: $23 / 05 / 2016$

Published: 25/09/2018

*Corresponding Author

Alamu 0.

E-mail: bisialamu@gmail.com

Keywords:

mango, adoption, innovation,

cultivation, incentives

\section{ABSTRACT}

Influence of the agricultural extension delivery on the adoption of mango production technologies in Oyo State was evaluated. A multistage sampling procedure was used to select the respondents. A well-structured questionnaire was used to obtain information in the study areas.Ten (10) respondents were randomly selected from each of the eight villages in the Zone. Socio-economic characteristics of the respondents and the level of adoption were also determined. Result of the analysis revealed that majority (90\%) of the respondents are married and of Christian faith (78.8\%). A majority $(87.5 \%)$ of the respondents specialized in crop farming. They admitted having had contact with extension agents and low level of adoption of the disseminated technologies. Majority (78.8\%) of the respondents involved in the cultivation of Ogbomoso mango. The test of hypotheses showed that there was no significant relationship between educational attainment and the adoption of technological innovation ( $r=$ 7.041, $p=0.317$ ). However, there was a significant relationship between the farming experience of the respondents and the adoption of the technological innovation $(r=13.054, p=0.042)$. 


\section{INTRODUCTION}

The need for food sufficiency and agricultural development in rural areas is one of the dominant issues in today's world. Effective and efficient agricultural extension delivery system is quintessential to agricultural and rural development in a developing economy such as Nigeria. Arokoyo (1998) observed that Training and Visit system of extension introduced into the World Bankassisted Agricultural Development Programmes (ADPs) had replaced the ineffective extension services of the erstwhile Ministries of Agriculture with greater outputs in Nigeria. However, the Agricultural Development Programmes (ADPs) in Nigeria have shown concrete proofs of its worth as a successful programe of agricultural transformation through a revitalized agricultural extension effort (World Bank, 1995; Adebayo and Idowu ,2000).

Nigeria is blessed with vast plant genetic resources for food and agriculture (PGRFA) including several fruit bearing tree crops with food and nutrition security potentials (FAO, 2008). Mango (Mangifera indica L.) is one of the oldest cultivated fruit trees and belongs to the family Anacardiaceae .Mango spread rapidly throughout the tropics where it is grown for its fruit and as a shade and ornamental tree. It is known to be among the most nutritious fruits. Each variety of mango is distinct from others in colour and flavour and therefore, varies in its suitability in processing into different products like juices and chutney (Raemeaekers, 2001). However, in most parts of Nigeria, Ogbomoso mango is a popular cultivar sought genotype primarily for its fruit flesh quality. This genotype of mango faces post harvest losses of up to $50 \%$ due to the high relative humidity, temperature and poor handling techniques and facilities (Awoh and Olorunda, 1981).

The sustainable production of fruit tree crops in sub Sahara Africa depends on access to inputs, production knowledge and a virile agricultural extension delivery system. Failure of the various extension delivery approaches in developing countries to effectively engineer significant and sustainable agricultural growth has become a major concern to all stakeholders, including the donor community.

Concerns on the inefficient extension delivery have been fueled lately by the wave of pluralism, market liberalization and globalization sweeping across the world and giving rise to initiatives that will enhance efficiency and effectiveness of not only the subcomponents of extension delivery but the entire system of technology generation, dissemination and use. Oyebanji (1994) observed that the performance of the extension services since the inception of this professional system has been encouraging. He noted that extension contacts with farmers have increased, while several technologies have been disseminated and adopted by farmers. However, Mijindadi (1992) reported that some prevailing problems existed and limited the effectiveness of the extension system. The problems include but not limited to insufficient funding at state level, inadequate availability of inputs, poor logistics support, and inadequate staffing. Consequent of the nutritional importance and economic importance of mango as an important fruit and export crop, there is the urgent need to evaluate the production chain vis-a - vis adoption of production and management technologies for sustainability. The objective of this study was to investigate the adoption of disseminated technologies related to mango production in the Ogbomoso Agricultural Zone of Oyo State.

\section{MATERIALS AND METHODS}

The study was carried out in Ogbomoso Agricultural Zone of Oyo State, Nigeria. The zone consists of five local government areas namely; Ogbomoso North, Ogbomoso South, Ogo- Oluwa, Surulere and Oriire Local Governments. The population of the study comprises all registered farmers with the Oyo State Agricultural Development Programme (OYSADEP) in the study area. Multistage random sampling procedure was used to select the respondents. At the first stage, four of the five local government areas in Ogbomoso Zone were purposely selected. Second stage involves the random selection of two villages in each local government area making a total of eight (8) villages. The last stage involves random selection of ten (10) farmers from each village making a total of eighty farmers (80). Data collected was analyzed with $\mathrm{Chi}$-square.

\section{RESULTS AND DISCUSSION}

\section{Demographic characteristics of the respondents}

Data from Table 1 showed that many (90\%) of the respondents were married while 8.8 and $1.3 \%$ were single and widowed respectively. $78.8 \%$ were Christians, while $21.3 \%$ were of Muslims faith respectively. Household size implies the total number of people staying under a roof and being fed. More than half $(56.3 \%)$ of the respondents have between $4-6$ household, $25 \%$ have between $7-9$ household, $2.5 \%$ have between 10 and above household, while $2.5 \%$ did not declare their household size. A higher number of children is an indication of family wealth in rural areas and this is in line with Ekong (2003) that majority of farmers marry more than one (1) wife for economic reasons. 
Table 1: Demographic characteristics of the respondents

\begin{tabular}{l|l|l}
\hline Category & Frequency & Percentage \\
\hline Marital status & 7 & 8.8 \\
Single & 72 & 90 \\
Married & 1 & 1.3 \\
Widowed & - & - \\
Divorced & 63 & \\
Religion & 17 & 78.8 \\
Christians & & 21.3 \\
Muslims & 11 & \\
Household size & 45 & 13.8 \\
$1-3$ & 20 & 56.3 \\
$4-6$ & 2 & 25.0 \\
$7-9$ & 37 & 2.5 \\
10 and above & 13 & \\
Educational attainment & 4 & 46.3 \\
Primary education & 26 & 16.3 \\
Secondary education & & 5.0 \\
Tertiary education & 70 & 32.5 \\
No formal education & 10 & \\
Primary occupation & 6 & 87.5 \\
Farming & 5 & \\
Others & 15 & 7.5 \\
Farming experience (years) & 54 & 6.3 \\
$1-3$ & & 18.8 \\
$4-6$ & $7-10$ & 67.5 \\
Above 10 years & &
\end{tabular}

Source: Field survey, 2013

Education is an important factor influencing the adoption of agricultural innovations. Data from Table 1 indicated that over half $(67.6 \%)$ of the respondents had some form of formal education, while $32.5 \%$ had no formal education. This implied that learned and educated people are involved in fruit crops production, which is in support of Solomon (2008) who noted that the majority of present day farmers had some formal education. High literacy among the respondents may facilitate the rate of adoption of innovations that are related to fruit crops production. Majority (87.5\%) of the respondents engaged in farming as primary occupation, while $12.5 \%$ engages in other occupations as primary occupation. This indicates that some of the farmers engaged in crop farming than other farming in the study area. Most $(67.5 \%)$ of the respondents have more than 10 years of farming experience, $18.8 \%$ have between $7-10$ farming experience, while $13.8 \%$ have been in farming for less than 7 years. If $1-10 y e a r s$ is classified as low farming tenure, then almost $70 \%$ of the respondents had high farming tenure.

Table 2 shows that most $(87.5 \%)$ of the respondents specialized in crop farming, $26.3 \%$ also specialized in agro forestry, while only $6.3 \%$ specialize in both poultry and integrated farming. This means that majority of the farmers in the study area are crop farmers.

Table 2: Respondents' area of agricultural enterprises

\begin{tabular}{l|l|l}
\hline Category & Frequency & Percentage \\
\hline Crop farming & 70 & 87.5 \\
Agro forestry & 21 & 26.3 \\
Piggery & 7 & 8.8 \\
Poultry & 5 & 6.3 \\
Integrated & 5 & 6.3 \\
Fishery & 1 & 1.3 \\
\hline Source: Field survey, 2013 & \multicolumn{2}{|c}{ Multiple responses }
\end{tabular}




\section{Respondents' contact with extension contact}

The results in Table 3 shows that most $(97.5 \%)$ of the respondents admitted having had contact with extension agents. This may be due to the locations of most them which tend to be more accessible to the extension agents than other villages.

Table 3: Contact with extension agents

\begin{tabular}{l|l|l}
\hline Category & Frequency & Percentage \\
\hline Yes & 78 & 97.5 \\
No & 2 & 2.5 \\
Total & 80 & 100 \\
\hline
\end{tabular}

Source: Field survey, 2013

Frequency of respondents' contact with extension agents

Table 4 shows that most $(92.5 \%)$ of the respondents admitted having had contact with extension agents on an unscheduled time i.e. anytime, $3.8 \%$ had contact with extension agents once in a year, while 1.3 had contact once weekly, monthly and quarterly. A majority (91.3\%) of the respondents admitted that the agents had visited to disseminate technological information, 53.8\% admitted they had visited to provide farm management guidance, while no respondent indicated the visit as marketing of farmers produce. However, 97.5\% responded that frequent contact with extension agents can help them to gain access to extension information and services.

Table 4: Frequency of respondents' contact with extension agents

\begin{tabular}{l|l|l}
\hline Category & Frequency & Percentage \\
\hline Weekly & 1 & 1.3 \\
Fortnightly & - & - \\
Monthly & 1 & 1.3 \\
Quarterly & 1 & 1.3 \\
Yearly & 3 & 3.8 \\
Anytime & 74 & 92.5 \\
\hline
\end{tabular}

Source: Field survey, 2013

\section{Technology dissemination and adoption}

Almost half $(47.5 \%)$ of the respondents were aware of the disseminated technologies on pest and diseases management but about only $20 \%$ adopted it . About $45 \%$ of the respondents were aware of the dissemination of technologies on improved seedlings but only about $15 \%$ adopted it. Only $16.3 \%$ of the respondents were aware of the technologies disseminated on rehabilitation techniques and a few $7.5 \%$ adopted it. However, it was observed that $38.8 \%$ of the population adopted technology on fire tracing. This was probably attributed to the devastating effects of forest fires on fruits trees and the need to proffer pragmatic solution to this.

Table 5: Technology dissemination and adoption

\begin{tabular}{l|l|l|l|l}
\hline Technology & Awareness & $\%$ & Adoption & $\%$ \\
\hline Soil/site selection & 32 & 40 & 11 & 13.8 \\
Fertilizer regime & 13 & 16.3 & 6 & 7.5 \\
Improved seedlings & 36 & 45 & 12 & 15 \\
Plant density & 33 & 41.3 & 12 & 15 \\
Fire tracing & 33 & 41.3 & 31 & 38.8 \\
Pest and disease management & 38 & 47.5 & 16 & 20 \\
Post harvest processing & 24 & 30 & 3 & 3.8 \\
Field establishment & 21 & 26.3 & 20 & 25 \\
\hline
\end{tabular}

Source: Field survey, 2013 
improved technologies was group method, $27.5 \%$ stated that the adopted method was individual method, while none of the respondent indicated the use of mass method.

Table 6: Methods of extension delivery

\begin{tabular}{l|l|l}
\hline Methods & F & $\%$ \\
\hline Individual & 22 & 27.5 \\
Group & 58 & 72.5 \\
Mass media & - & - \\
\hline
\end{tabular}

Source: Field survey, 2013

\section{Sources of information available to the respondents}

The result of the analysis revealed that majority (75\%) of the respondents consulted agricultural extension agents to find solution when they have production problems,
$31.3 \%$ of them discussed their farming problems with fellow farmers, while only $6.3 \%$ often go to Ministry of Agriculture and community leaders to get their problem solved.

Table 7: Respondents' sources of information

\begin{tabular}{l|l|l}
\hline Sources of Information & $\mathbf{F}$ & $\%$ \\
\hline Extension agents & 60 & 7.5 \\
Ministry of Agriculture & 5 & 6.3 \\
Farmers organizations & 8 & 10 \\
Fellow farmers & 25 & 31.3 \\
Community leaders & 5 & 6.3 \\
\hline
\end{tabular}

Source: Field survey, 2013

\section{Mango variety cultivated}

Majority $(78.8 \%)$ of the respondents involved in the cultivation of Ogbomosho mango, $65 \%$ of them cultivated Cherry Ogbomoso. $35 \%$ of them cultivated Jekanoyo, while only $10 \%$ of them involved in the cultivation of Olori palaba.

Table 8: Distribution of mango variety cultivated

\begin{tabular}{l|l|l}
\hline Variety & $\mathbf{F}$ & $\%$ \\
\hline Ogbomosho mango & 63 & 78.8 \\
Cherry Ogbomosho & 52 & 65 \\
Cherry oyo & 20 & 25 \\
Baafin & 15 & 18.8 \\
Olori palaba & 8 & 10 \\
Jekanoyo & 28 & 35 \\
Olomi & 25 & 31.3 \\
\hline Source: Field survey, 2013 & \multicolumn{2}{|l}{ * Multiple response }
\end{tabular}

\section{Testing of hypotheses}

Hypothesis one $\left(\mathrm{H}_{0} \mathbf{1}\right)$ : There is no significant relationship between educational attainment of the respondents and the adoption of technological innovation. Result in Table 9 shows that there is no significant relationship between educational attainment and the adoption of technological innovations $(r=7.041$, $p=0.317$ ). Thus, the null hypothesis is accepted. This indicated that adoption of technological innovations has nothing to do with the education of the respondents.

Table 9: Chi-square test indicating relationship between educational attainment, farming experience and their relationship between adoption of technological innovations

\begin{tabular}{|l|l|l|l|l|}
\hline Variables & r-value & p-value & Remarks & Decision \\
\hline Educational attainment & 7.041 & 0.317 & NS & Accept $\mathrm{H}_{0}$ \\
\hline farming experience (years) & 13.054 & 0.042 & $\mathrm{~S}$ & Reject $\mathrm{H}_{0}$ \\
\hline
\end{tabular}

$p>0.05=N S, P<0.05=S$ 
Hypothesis one $\left(\mathbf{H}_{\mathrm{o}} \mathbf{2}\right)$ : There is no significant relationship between the years of farming experience of the respondents and the adoption of technological innovation. Table 9 shows that there is a significant relationship between the years of the farming experience of the respondents and adoption of the technological innovation $(r=13.054, p=0.042)$. Therefore, the null hypothesis is rejected. This implied that years of farming experience has perceived effect on the adoption of technological innovation.

\section{CONCLUSION}

It is concluded that majority of the respondents are married and of Christian faith. More than half of them have between 4-6 members per household. The result shows that over half of respondents had some form of formal education. Majority of the respondents engaged in farming as primary occupation, while they have more than 10 years of farming experience. Most of them specialize in crop farming, while they admitted having contact with extension agents on an unscheduled time. Almost half of the respondents are aware of the disseminated technologies on pest and disease management. Generally, there was low level in the adoption of technologies disseminated through extension delivery in the Zone. The farmers agreed that group method of extension delivery is the most commonly used extension method for dissemination of improved technologies. Majority of the respondents consulted extension agents to find solution when they have farming problems. Thus, this study emphasized the pivotal roles of extension delivery services of Agricultural Development Programmes (ADP's) to the development of agricultural sector in Oyo State and Nigeria in general. Based on the conclusion of this study, the following recommendations are made:

1. Youth should be encouraged to be actively involved in farming by providing incentives to them.

2. Ministry of Agriculture should be advised to create more awareness or avenue for farmers visit in order to bring their problems for solution.

\section{REFERENCES}

Adebayo, K. and Idowu,T. A. (2000). The aftermath of the withdrawal of the World Bank counterpart funding for the Ogun State Agricultural Development Programme in Nigeria, Journal of Sustainable Agriculture Vol. 17(2/3) pp. 79-93.

Arokoyo, T. (1998). Agricultural Technology Development and Dissemination: A Case of Ghana and Nigeria Experiences. Technical Center for Agriculture and Rural Cooperation, Wageningen.

Aworh, O.C. and Olorunda, A.O. (1981). Post- harvest losses of perishable fruits and vegetables in Nigeria.Proceedings of the National Conference of Agriculture. Port Harcourt 3-8 May, 1981.

Ekong, E.E. (2003). An introduction to Rural Sociology, Uyo. Dov Educational Publishers, pp 201-202.

FAO (2008). State of Plant Genetic Resources for Food and Agriculture in Nigeria. A Country Report. Food and Agriculture Organization of the United Nations 82pp

Idachaba, F.S. (2005). Agricultural and Rural Development in Nigeria. The policy perspective. A text of convocation Lecture Delivered at K.S.U. Anyigba on $11^{\text {th }}$ March 2005 pp $3-4$.

Mijindadi, N.B. (1992). Agricultural Extension Service approaches in Africa. Emerging Issues and Lessons from Nigeria's Experiences. Paper Presented at the Conference of African Farm Management Association, Held at Harare, Zimbabwe

Oyebanji, O.O. (1994). The Development of Agricultural Extension in Nigeria, Agricultural Extension in Africa. Vol. 2. Proceedings of an International Workshop. Yaounde, Cameroun. Post Bus, AJ Wageningen. The Netherlands: Technical Centre for Agric \& Rural Dev. p. 240.

Romain, H.R. (2001). Crop Production in Tropical Africa. Directorate General for International Cooperation (DGIC) Brussels, Belgium 1640 pp.

Solomon, O. (2008). Small scale oil palm farmer's perception of organic agriculture in Imo State, Nigeria, Journal of Environmental Extension. 7: 6771.

World Bank (1995). Nigeria and the World Bank: Learning from the fast, looking to the future. The World Bank, Washington DC. 